\title{
Sprayed and Spin-Coated Multilayer Antireflection Coating Films for Nonvacuum Processed Crystalline Silicon Solar Cells
}

\author{
Abdullah Uzum, ${ }^{1,2}$ Masashi Kuriyama, ${ }^{1}$ Hiroyuki Kanda, ${ }^{1}$ Yutaka Kimura, ${ }^{3}$ \\ Kenji Tanimoto, ${ }^{3}$ Hidehito Fukui, ${ }^{4}$ Taichiro Izumi, ${ }^{4}$ Tomitaro Harada, ${ }^{4}$ and Seigo Ito ${ }^{1}$ \\ ${ }^{1}$ Department of Materials and Synchrotron Radiation Engineering, Graduate School of Engineering, University of Hyogo, \\ 2167 Shosha, Himeji, Hyogo 671-2280, Japan \\ ${ }^{2}$ Department of Electrical and Electronics Engineering, Graduate School of Engineering, Karadeniz Technical University, \\ 61080 Trabzon, Turkey \\ ${ }^{3}$ Specialty Materials Research Laboratory, Nissan Chemical Industries Ltd., 11-1 Kitasode, Sodegaurashi, Chiba 299-0266, Japan \\ ${ }^{4}$ Daiwa Sangyo Co. Ltd., 3-4-11, Nakayasui, Sakai, Sakai, Osaka, Japan \\ Correspondence should be addressed to Seigo Ito; itou@eng.u-hyogo.ac.jp
}

Received 15 October 2016; Revised 8 December 2016; Accepted 14 December 2016; Published 2 January 2017

Academic Editor: Nini R. Mathews

Copyright (C) 2017 Abdullah Uzum et al. This is an open access article distributed under the Creative Commons Attribution License, which permits unrestricted use, distribution, and reproduction in any medium, provided the original work is properly cited.

Using the simple and cost-effective methods, spin-coated $\mathrm{ZrO}_{2}$-polymer composite/spray-deposited $\mathrm{TiO}_{2}$-compact multilayer antireflection coating film was introduced. With a single $\mathrm{TiO}_{2}$-compact film on the surface of a crystalline silicon wafer, $5.3 \%$ average reflectance (the reflectance average between the wavelengths of $300 \mathrm{~nm}$ and $1100 \mathrm{~nm}$ ) was observed. Reflectance decreased further down to $3.3 \%$ after forming spin-coated $\mathrm{ZrO}_{2}$ on the spray-deposited $\mathrm{TiO}_{2}$-compact film. Silicon solar cells were fabricated using CZ-Si p-type wafers in three sets: (1) without antireflection coating (ARC) layer, (2) with $\mathrm{TiO}_{2}$-compact ARC film, and (3) with $\mathrm{ZrO}_{2}$-polymer composite/ $\mathrm{TiO}_{2}$-compact multilayer ARC film. Conversion efficiency of the cells improved by a factor of $0.8 \%$ (from $15.19 \%$ to $15.88 \%$ ) owing to the multilayer ARC. $J_{\mathrm{sc}}$ was improved further by $2 \mathrm{~mA} \mathrm{~cm}^{-2}$ (from $35.3 \mathrm{~mA} \mathrm{~cm}^{-2}$ to $37.2 \mathrm{~mA} \mathrm{~cm}^{-2}$ ) when compared with a single $\mathrm{TiO}_{2}$-compact ARC.

\section{Introduction}

In order to achieve high efficiency silicon solar cells, reducing the optical losses and improving the absorption properties of the cell are one of the key factors. To minimize the reflection of the solar cell surface, a range of material and thin films have been used for ARC purposes for solar cells $\left(\mathrm{SiO}, \mathrm{SiO}_{2}, \mathrm{SiN}_{x}\right.$, $\mathrm{TiO}_{2}, \mathrm{Al}_{2} \mathrm{O}_{3}, \mathrm{ZnS}$ thin films, etc.) depending to the type of solar cell. Although a single ARC coating layer can minimize the reflection less than $1 \%$ only at a single wavelength, a multilayer structure with gradual increase of refractive index on the light path is necessary in order to achieve improved reflectivity along the spectrum [1]. In this case, it is necessary to build multilayer structure by considering the gradual increase order of refractive indexes as air $<1$ st layer $<$ 2nd layer $<\cdots<n$th layer $<$ silicon. Considering the optimum refractive index for a single ARC layer between air and silicon according to $n_{1}=\left(n_{0} n_{s}\right)^{-1 / 2}\left(n_{s}, n_{0}\right.$, and $n_{1}$ : refractive index of silicon, air, and ARC thin film, resp.), one could consider that widely in use $\operatorname{SiN}_{x}(n=1.97)$ might be the optimum material for ARC layer for silicon solar cells [1]. Quality forming of ARC coating materials mostly utilizes a type of chemical vapor deposition (CVD) technique. In case of $\mathrm{SiN}_{x}$ films, for instance, typically a plasma-enhanced chemical vapor deposition (PECVD) technique $[2,3]$ is used. Taking the advantage of tunability of the refractive index of $\mathrm{SiN}_{x}$ by changing the deposition parameters of PECVD [4], better reflection performances with multilayer stacks of $\mathrm{SiN}_{x}$ are achievable. Although, it is a well-established technology and has advantages including the high deposition rate, the need of toxic and hazardous gases such as $\mathrm{SiH}_{4}$ (silane), $\mathrm{SiH}_{2} \mathrm{Cl}_{2}$ (dichlorosilane), and $\mathrm{NH}_{3}$ (ammonia) with high vacuum processing for CVD operation and considerably high costs come along as the major drawbacks. Considering these 
disadvantages and the fact that low-cost and high throughput are a continuous demand for silicon solar cell industry, simple low-cost technologies with high throughput, cost-effective methods need to be investigated and adapted to the solar cell manufacturing process.

In literature, $\mathrm{TiO}_{2}$ has been widely investigated as an alternative ARC layer for crystalline silicon solar cells $[5,6]$, due to its good optical properties that enhance the light absorption capability because of the high refractive index for silicon solar cell. Solution processed materials for silicon solar cells including $\mathrm{TiO}_{2}, \mathrm{TiO}_{2}-\mathrm{SiO}_{2}[5,6]$, and $\mathrm{Al}_{2} \mathrm{O}_{3}$ based $\mathrm{Ti}$ doped mixed sol-gel sources have been introduced as well $[7,8]$. Although there is a considerable amount of research regarding such alternative materials for ARC, mainly based on $\mathrm{TiO}_{2}$ and $\mathrm{SiO}_{2}$ solutions, the availability of proper material and combined structures is still limited. Various techniques can be used in principle to form such precursors on the substrate homogenously, including spin coating $[9,10]$, spray pyrolysis, or dip-coating [11-13]. These practical and low-cost techniques have advantages including simple deposition of thin films from the prepared precursor solutions. Utilizing such techniques also leads an opportunity of using a broad range of chemicals with flexible amounts for both high or low temperature applications.

Additionally, $\mathrm{ZrO}_{2}$ thin films with good optical properties and both chemical and mechanical stabilities [14, 15] have been investigated initially for dye synthesized solar cells to enhance the properties of polymers [14], as well as improve the antireflection property of solar module glasses [16]. With the attractive optical properties, high refractive index and good thermal stability $\mathrm{ZrO}_{2}$ films can be another promising candidate for ARC layer of silicon solar cells $[17,18]$.

In this work, as a low temperature and nonvacuum method, spin-coating deposition was performed for $\mathrm{ZrO}_{2}-$ polymer composite films and spray pyrolysis deposition method was performed for $\mathrm{TiO}_{2}$-compact film and $\mathrm{ZrO}_{2}$ polymer composite/ $\mathrm{TiO}_{2}$-compact multilayer films were introduced as an alternative ARC film for silicon solar cells. After confirming the structure of $\mathrm{TiO}_{2}$ and $\mathrm{ZrO}_{2}$ polymer based thin films separately, $\left\langle\mathrm{air} / \mathrm{ZrO}_{2} / \mathrm{TiO}_{2} / \mathrm{Si}\right\rangle$ multilayer structure was also built considering the gradual increase order of refractive indexes. And after the experimental evaluations, silicon solar cells were fabricated with and without using $\mathrm{TiO}_{2}$-compact film or $\mathrm{ZrO}_{2}$-polymer composite/ $\mathrm{TiO}_{2}$ compact film multilayer films.

\section{Experimental}

Spray-deposited $\mathrm{TiO}_{2}$-compact films and spin-coating $\mathrm{ZrO}_{2}-$ polymer composite films were formed on alkaline textured crystalline silicon (c-Si) substrates for primary evaluation of the coated films in terms of optical and physical analysis. Afterwards, textured surface p-type CZ-Si solar cells were fabricated using $\mathrm{TiO}_{2}$-compact films and $\mathrm{ZrO}_{2}$-polymer composite/ $/ \mathrm{TiO}_{2}$-compact multilayer film as an antireflection coating (ARC) layer on the front surface of the c-Si wafers and were compared to those of solar cells without ARC.

For the optical measurements, square-shaped p-type silicon wafers $\left(25 \times 25 \mathrm{~mm}^{2}\right)$ were cut out from 6-inch CZ-Si p-type wafers. All wafers were dipped into the $20 \%$ diluted $\mathrm{HF}$ for $1 \mathrm{~min}$ and rinsed in distilled water. Afterwards, $\mathrm{UV} / \mathrm{O}_{3}$ surface treatment was carried out for a complete cleaning process. $\mathrm{ZrO}_{2}$-polymer composite film was deposited on silicon substrate by spin coating using the zirconium sol (ZR-30AH, provided by Nissan Chemical Industry Co. Ltd., Chiba, Japan). The investigation and optimization of $\mathrm{ZrO}_{2}$ based solutions were introduced in our previous works [19] in order to use them for silicon solar cell applications with flat or textured surfaces. According to these works, optimized $\mathrm{ZrO}_{2}$ solution composed by ethyl cellulose, ethanol, and ZR-30AH in ratio of $2: 16: 1$ (in volume) was used in this work as well. Deposition of the $\mathrm{ZrO}_{2}$ film was carried out by spin coating with a spin speed of $1500 \mathrm{rpm}$ for $25 \mathrm{~s}$ (acceleration time is $5 \mathrm{~s})$.

$\mathrm{TiO}_{2}$ compact films were formed on the silicon wafers by spray pyrolysis deposition using precursor solutions which was sprayed on to the surface of silicon wafers using a glass atomizer. The crystalline silicon wafers were set on a hot plate heated at deposition temperature of $450^{\circ} \mathrm{C}$. The $\mathrm{TiO}_{2}$ precursor solution was prepared by the ten-time dilution of titanium di-isopropoxidebis-acethylacetone (TAA) (prepared by mixing titanium (VI) isopropoxide and acetylacetone by $1: 2$ in mole) to ethanol. Annealing temperature was optimized for $\mathrm{TiO}_{2}$ as $450^{\circ} \mathrm{C}$ and as $125^{\circ} \mathrm{C}$ for $\mathrm{ZrO}_{2}$, respectively. Analyses were mainly carried out by reflection analysis (by ultraviolet-visible spectroscopy, Lambda 750 UV/VIS Spectrometer, Perkin Elmer, Waltham, MA, USA) and ellipsometer (UviselErAgms-nds, Horiba Jobin Yvon, Kyoto, Japan) and finally by the performance of the fabricated silicon solar cells with or without ARC.

Silicon solar cells were fabricated with a variety of final surface conditions: without ARC on textured surface, with $\mathrm{TiO}_{2}$-compact film on textured surface, and with $\mathrm{ZrO}_{2}$ polymer composite/ $/ \mathrm{TiO}_{2}$-compact multilayer ARC film on textured surface. For the fabrication of silicon solar cells, $25 \mathrm{~mm} \times 25 \mathrm{~mm}$ p-type CZ-Si wafers were used as well. For textured surface, alkaline texturing was performed in $\mathrm{KOH}$ (5.19 g) solution in $\mathrm{H}_{2} \mathrm{O}(100 \mathrm{~mL})$ with Alka-Tex $(0.28 \mathrm{~mL}, \mathrm{GP}$ Solar, Konstanz, Germany) at $80^{\circ} \mathrm{C}$ (set: $100^{\circ} \mathrm{C}$ ) for $30 \mathrm{~min}$. The silicon wafers were dipped into the $20 \%$ diluted HF for $10 \mathrm{~min}$ and rinsed in distilled water. Then, RCA cleaning $[20,21]$ was carried out to remove contaminant particles on the surface of the wafers by using a $\mathrm{NH}_{4} \mathrm{OH} / \mathrm{H}_{2} \mathrm{O}_{2} / \mathrm{H}_{2} \mathrm{O}$ (1:1:5 in volume) solution, for $10 \mathrm{~min}$ at $80^{\circ} \mathrm{C}$. After removal of the natural oxide films by $20 \% \mathrm{HF}$, a mix solution of $\mathrm{HCl} / \mathrm{H}_{2} \mathrm{O}_{2} / \mathrm{H}_{2} \mathrm{O}$ (1:1:5 in volume) was used to remove metallic contaminations and mobile ions on the surface by dipping the wafers for $10 \mathrm{~min}$ at $80^{\circ} \mathrm{C}$. In order to prevent phosphorous diffusion and to prevent the texture on the back side of the silicon wafer, polysilazane was coated using spincoating method by two times at $1500 \mathrm{rpm}$ for $20 \mathrm{~s}$, succeeded by annealing at $600^{\circ} \mathrm{C}$ for $60 \mathrm{~min}$ in $\mathrm{O}_{2}$ gas flow. $\mathrm{POCl}_{3}$ diffusion was performed at $930^{\circ} \mathrm{C}$ for $35 \mathrm{~min}$ with $0.2 \mathrm{l} / \mathrm{min}$ $\mathrm{N}_{2}$ flow, to form $\mathrm{n}^{+}$emitter. Afterwards, wafers were rinsed in $10 \% \mathrm{HF}$ and pure water by dipping, successively. $\mathrm{SiO}_{2}$ film was formed by thermal oxidation process at temperature of $800^{\circ} \mathrm{C}$ for $10 \mathrm{~min}$ under $\mathrm{O}_{2}$ gas. Before the metallization process, wafers were set on a hot plate heated at deposition 


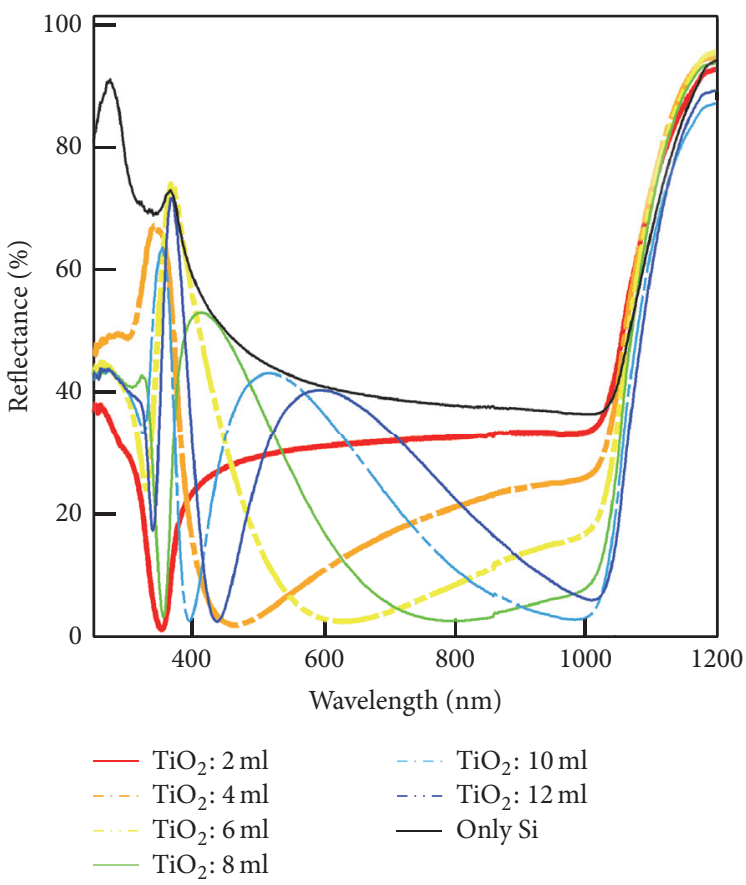

(a)

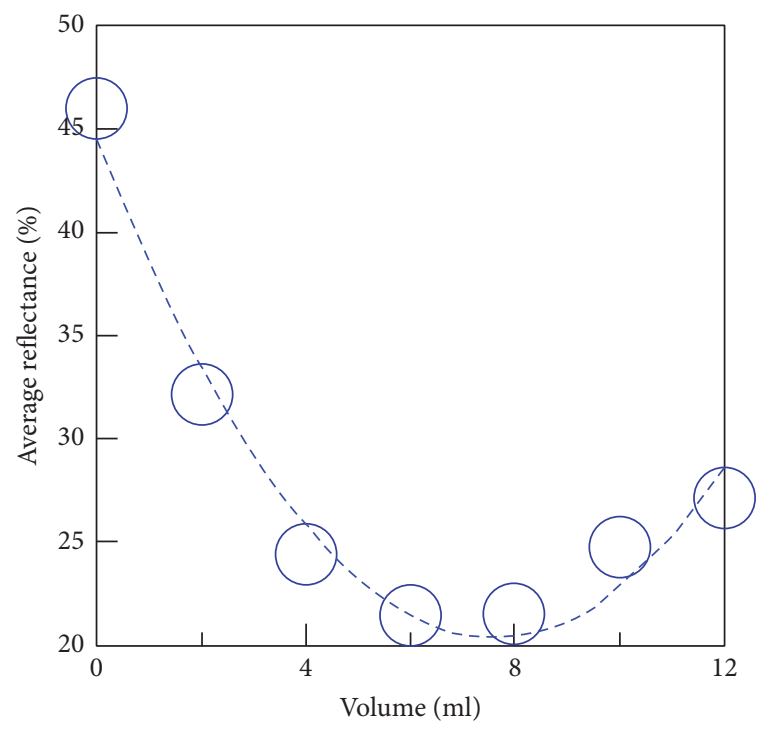

(b)

FIgURE 1: Comparison of the reflectivity of the flat samples with $\mathrm{TiO}_{2}$ antireflection coatings by various amount $\mathrm{TiO}_{2}$ precursor solution. (a) Reflectance spectra depending on spraying amount. (b) Average reflectance (300-1100 nm wavelength) depending on spraying amount.

temperature $\left(450^{\circ} \mathrm{C}\right)$ and deposition of $\mathrm{TiO}_{2}$ films were carried out by spray pyrolysis. Then, front and back contacts were formed by screen-printing $\mathrm{Ag}$ and $\mathrm{Al}$, respectively. Cofiring was carried out at $780^{\circ} \mathrm{C}$ for $1 \mathrm{~min}$ in an oven. After evaluating the solar cells with a single layer $\mathrm{TiO}_{2}$-compact films on the wafer surfaces, $\mathrm{ZrO}_{2}$-polymer composite films were deposited on the finished cells and compared to those of the cells without ARC and with single layer $\mathrm{TiO}_{2}$-compact films. Deposition of $\mathrm{ZrO}_{2}$-polymer composite ARC films was carried out by the annealing step after spin-coating process (1000 rpm on flat surface, $1500 \mathrm{rpm}$ on textured surface, $5 \mathrm{~s}$ acceleration $+25 \mathrm{~s}$, annealing at $125^{\circ} \mathrm{C}, 5 \mathrm{~min}$ ).

\section{Results and Discussion}

In order to evaluate the reflectivity performance of single layer $\mathrm{TiO}_{2}$-compact film, flat surface silicon wafers were used. Figure 1(a) shows the comparison of the reflectivity of flat samples w/or w/o $\mathrm{TiO}_{2}$-compact film on silicon surface. The thickness of the $\mathrm{TiO}_{2}$ film was mainly controlled by the spraying amount of $\mathrm{TiO}_{2}$ precursor solution in a range of $0 \sim 12 \mathrm{~mL}$. Depending the film thickness, minimum of the reflectance $(<2 \%)$ shifts towards to the longer wavelengths. A steep decrease before the minimum can be confirmed for all $\mathrm{TiO}_{2}$ film coated surfaces. As can be confirmed in Figure 1(a), the minimum of the reflectance shifts to the wavelengths as high as around $1000 \mathrm{~nm}$ for the films coated with 10 and $12 \mathrm{~mL} \mathrm{TiO}_{2}$ precursors. The average reflectivity (the reflectance average between the wavelength of $300 \mathrm{~nm}$ and $1100 \mathrm{~nm}$ ) was plotted by changing the spraying amount of the $\mathrm{TiO}_{2}$ precursor as $0 \mathrm{~mL}, 2 \mathrm{~mL}, 4 \mathrm{~mL}, 6 \mathrm{~mL}, 8 \mathrm{~mL}, 10 \mathrm{~mL}$,
TABLE 1: Average reflectance (between 300 and $1100 \mathrm{~nm}$ ) of texture surface silicon substrate with $\mathrm{ZrO}_{2}$-polymer ARC (adapted from our previous work [19]).

\begin{tabular}{lccccc}
\hline Spin speed (rpm) & 500 & 1000 & 1500 & 2000 & 3000 \\
Average reflectance (\%) & 9.15 & 7.77 & 6.91 & 7.1 & 6.84 \\
\hline
\end{tabular}

and $12 \mathrm{~mL}$, respectively (Figure 1(b)). A deposition rate of $\mathrm{TiO}_{2}$ is defined as $10.1 \mathrm{~nm} \mathrm{~mL}^{-1}$ according to ellipsometry measurements. The lowest average reflectance of $21.41 \%$ was achieved by spray-deposited $\mathrm{TiO}_{2}$ coating with a thickness of $60.6 \mathrm{~nm}$.

The bottom of reflectance valley shifted to higher wavelength with increasing the solution volume from $2 \mathrm{~mL}$ to $12 \mathrm{~mL}$, gradually. Using the $8 \mathrm{~mL}$ precursor solution, the second valley arouse at the lower wavelength which was close to the valley bottom of $2 \mathrm{~mL}$ precursor solution. The second valley at the lower wavelength was also shifted to the larger wavelength with increasing the precursor solution.

$\mathrm{ZrO}_{2}$-polymer composite films were formed on textured silicon surface by a spin speed of $1500 \mathrm{rpm}$ for $25 \mathrm{~s}$ (acceleration time is $5 \mathrm{~s}$ ), based on our preliminary work of $\mathrm{ZrO}_{2}$-polymer composite films as an ARC layer for silicon solar cells [19]. Such a $\mathrm{ZrO}_{2}$-polymer composite film has a thickness of $102 \mathrm{~nm}$ on flat silicon surface and was used in combination with $\mathrm{TiO}_{2}$-compact film in this work. The average reflectivity (the reflectivity average between $300 \mathrm{~nm}$ and $1100 \mathrm{~nm}$ ) of $\mathrm{ZrO}_{2}$-polymer films deposited on textured surface with various spin speeds was given in Table 1 where a good optical performance can be confirmed with average 
TABLE 2: Photovoltaic characteristics of fabricated crystalline silicon solar cells with various surface structures with/without antireflection coating on textured surface.

\begin{tabular}{|c|c|c|c|c|c|c|c|}
\hline Surface structure & ARC & $J_{\mathrm{sc}}\left(\mathrm{mA} \mathrm{cm}^{-2}\right)$ & $V_{\mathrm{oc}}(\mathrm{V})$ & $\mathrm{FF}(\%)$ & $R_{\text {series }}\left(\Omega \mathrm{cm}^{2}\right)$ & $R_{\text {shunt }}\left(\Omega \mathrm{cm}^{2}\right)$ & $\eta(\%)$ \\
\hline Textured & - & 28.7 & 0.511 & 69.4 & 0.71 & 250 & 10.2 \\
\hline Textured & $\mathrm{TiO}_{2}$-compact & 35.3 & 0.581 & 74.1 & 0.40 & 655 & 15.2 \\
\hline Textured & $\mathrm{ZrO}_{2}$-polymer $/ \mathrm{TiO}_{2}$-compact & 37.2 & 0.583 & 73.4 & 0.45 & 535 & 15.9 \\
\hline
\end{tabular}

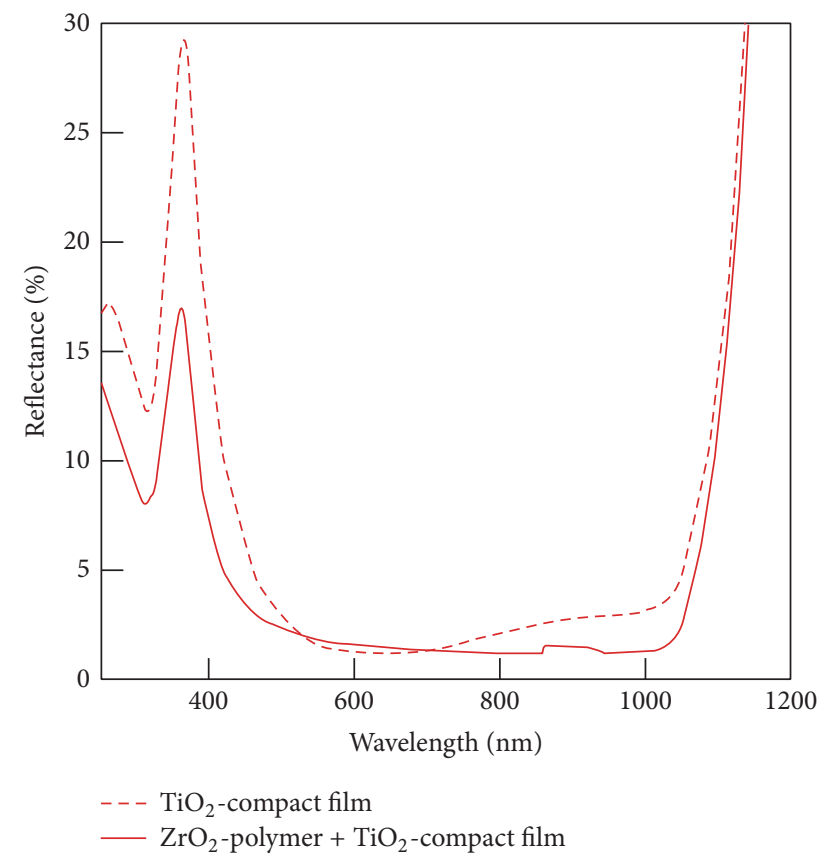

Figure 2: Comparison of the reflectivity of the textured silicon wafers with $\mathrm{TiO}_{2}$ single layer and spin-coated $\mathrm{ZrO}_{2} /$ spray-deposited $\mathrm{TiO}_{2}$ double layer.

reflectivity of $6.91 \%$. The slight increase of average reflectance for $2000 \mathrm{rpm}$ was considered as intolerance due to the possible local inhomogeneity of the film.

In case of reflectivity measurement for $\mathrm{ZrO}_{2}$-polymer composite/ $/ \mathrm{TiO}_{2}$-compact multilayer, first, $\mathrm{TiO}_{2}$-compact single layer was formed and measured and then $\mathrm{ZrO}_{2}$-polymer composite was formed on $\mathrm{TiO}_{2}$ covered surface and remeasured. The comparison of reflectivity of $\mathrm{TiO}_{2}$-compact single layer with the $\mathrm{ZrO}_{2}$-polymer composite/ $/ \mathrm{TiO}_{2}$-compact multilayer formed on textured silicon wafers is given in Figure 2. The average reflectance was improved further with applying $\mathrm{ZrO}_{2}$-polymer composite to the $\mathrm{TiO}_{2}$-compact film, offering between 5 and 12\% reflectance gain from $300 \mathrm{~nm}$ to $450 \mathrm{~nm}$ and a steady lower reflectance tendency from wavelength of around 700 to $1000 \mathrm{~nm}$ can also be confirmed.

Finally, silicon solar cells were fabricated using textured $\mathrm{CZ}-\mathrm{Si}$ p-type wafers with and without using the $\mathrm{ZrO}_{2}$ polymer antireflection composite layer on $\mathrm{TiO}_{2}$-compact film. Conversion efficiency of the cells improved from $15.2 \%$ to $15.9 \%$, where the $J_{\mathrm{sc}}$ also increased further from $35.3 \mathrm{~mA} \mathrm{~cm}^{-2}$ to $37.2 \mathrm{~mA} \mathrm{~cm}^{-2}$ owing to the $\mathrm{ZrO}_{2} / \mathrm{TiO}_{2}$ multilayer ARC film (the $J_{\mathrm{sc}}$ of the cell without ARC was

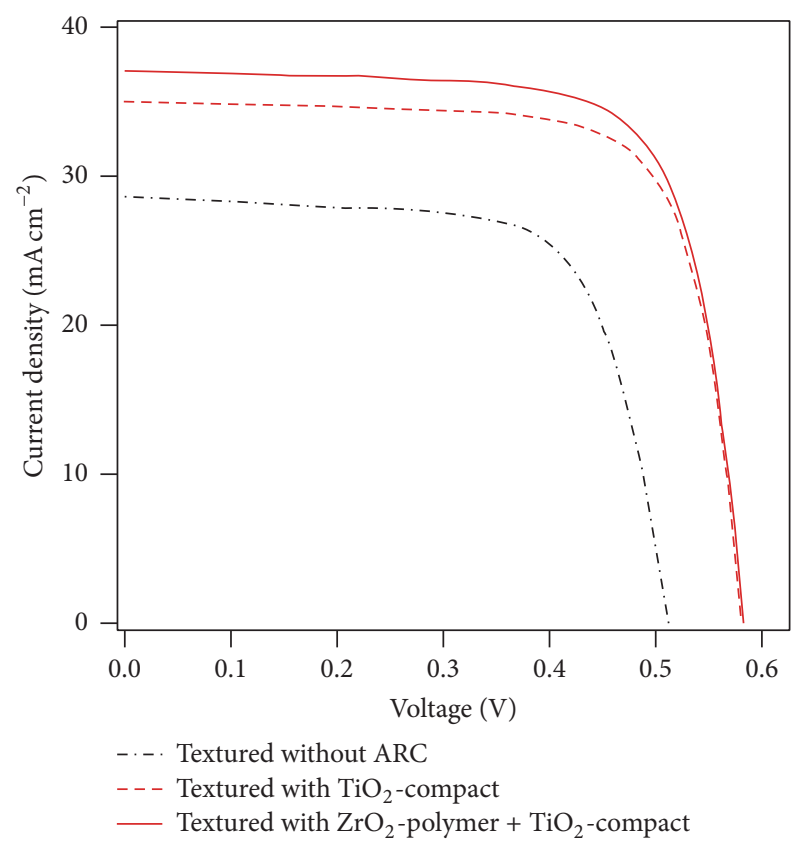

FIGURE 3: $J-V$ curve comparison of the best cells with or without antireflection coating.

$28.7 \mathrm{~mA} \mathrm{~cm}^{-2}$ ). The electrical characteristics of the cells are summarized in Table 2.

$70 \mathrm{mV}$ increase of $V_{\text {oc }}$ of the cells with ARC can be confirmed. Though $\mathrm{SiO}_{2}$ film was formed by thermal oxidation process at temperature of $800^{\circ} \mathrm{C}$ for $10 \mathrm{~min}$ under $\mathrm{O}_{2}$ gas, we did not compare the photovoltaic results with/without $\mathrm{SiO}_{2}$ layer. Hence, the increase of $V_{\text {oc }}$ is due to the compact $\mathrm{TiO}_{2}$ layer, which can prevent excessive fire of Ag into p-n junction. The greater FF of the cells with ARC layer can be attributed to the lower contact resistances in which the effect of additional $\mathrm{SiO}_{2}$ layer can be considerable in order to avoid internal shunts. $J-V$ characteristics of the silicon solar cells fabricated with $\mathrm{TiO}_{2}$-compact single layer and $\mathrm{ZrO}_{2}$-polymer composite $/ \mathrm{TiO}_{2}$-compact multilayer ARC on surface of the cells are given in Figure 3.

One can conclude that a significant improvement on $J_{\text {sc }}$ and $\eta$ could be confirmed owing to the $\mathrm{ZrO}_{2}$-polymer composite/ $/ \mathrm{TiO}_{2}$-compact multilayer ARC when compared to the textured cells without ARC. The increase of the $J_{\mathrm{sc}}$ was related to minimizing the reflectance loses which can boost the performance of the cell. These results suggest that $\mathrm{ZrO}_{2} / \mathrm{TiO}_{2}$ based multilayer ARC films formed by spray pyrolysis deposition technique and spin-coating technique 
could be an attractive alternative as a low-cost, simple, and vacuum-less process for ARC coating for silicon solar cells.

\section{Conclusion}

$\mathrm{TiO}_{2}$-compact and $\mathrm{ZrO}_{2}$-polymer composite antireflection coating layers were introduced as an alternative ARC layers for silicon solar cells. Films were formed by simple and cost-effective spray pyrolysis deposition and spincoating process. Reflectance decreased further with $\mathrm{ZrO}_{2}-$ polymer composite/ $\mathrm{TiO}_{2}$-compact layer comparing to the single $\mathrm{TiO}_{2}$-compact film formed surface. Less than $2 \%$ surface reflectance was confirmed after applying $\mathrm{ZrO}_{2}-$ polymer composite/ $/ \mathrm{TiO}_{2}$-compact multilayer in a wide range of spectra, from around $550 \mathrm{~nm}$ to $1050 \mathrm{~nm}$. Silicon solar cells were fabricated using CZ-Si p-type wafers both with and without ARC layers on the illuminated surface. Conversion efficiency of the cells improved by a factor of $0.8 \%$ with ARC and reaches $15.9 \%$ efficiency where the $J_{\text {sc }}$ increased further by $2 \mathrm{~mA} \mathrm{~cm}^{-2}$ (from $35.3 \mathrm{~mA} \mathrm{~cm}^{-2}$ to $37.2 \mathrm{~mA} \mathrm{~cm}^{-2}$ ) owing to the $\mathrm{ZrO}_{2}$-polymer composite/ $/ \mathrm{TiO}_{2}$-compact multilayer ARC. These results indicate that $\mathrm{ZrO}_{2}$-polymer composite films can be an attractive candidate as an ARC film and for multilayer ARC structures in order to produce cost-effective solar cells.

\section{Competing Interests}

The authors declare no conflict of interests.

\section{References}

[1] J. Nelson, The Physics of Solar Cells, Imperial College Press, London, UK, 2003.

[2] A. G. Aberle and R. Hezel, "Progress in low-temperature surface passivation of silicon solar cells using remote-plasma silicon nitride," Progress in Photovoltaics, vol. 5, no. 1, pp. 29-50, 1997.

[3] Y. Wan, K. R. McIntosh, and A. F. Thomson, "Characterisation and optimisation of PECVD SiNx as an antireflection coating and passivation layer for silicon solar cells," AIP Advances, vol. 3, no. 3, Article ID 032113, 2013.

[4] D. R. Wright, E. S. Marstein, and A. Holt, "Double layer antireflective coatings for silicon solar cells," in Proceedings of the 31st IEEE Photovoltaic Specialist Conference, pp. 1237-1240, 2005.

[5] C. J. Brinker and M. S. Harrington, "Sol-gel derived antireflective coatings for silicon," Solar Energy Materials, vol. 5, no. 2, pp. 159-172, 1981.

[6] B. S. Richards, "Single-material $\mathrm{TiO}_{2}$ double-layer antireflection coatings," Solar Energy Materials and Solar Cells, vol. 79, no. 3, pp. 369-390, 2003.

[7] P. Vitanov, X. Loozen, A. Harizanova, T. Ivanova, and G. Beaucarne, "A study of sol-gel deposited $\mathrm{Al}_{2} \mathrm{O}_{3}$ films as passivating coatings for solar cells application," in Proceedings of the 23rd European Photovoltaic Solar Energy Conference and Exhibition, pp. 1596-1599, Valencia, Spain, September 2008.

[8] Z. Liang, D. Chen, C. Feng, J. Cai, and H. Shen, "Crystalline silicon surface passivation by the negative charge dielectric film," Physics Procedia, vol. 18, pp. 51-55, 2011.
[9] P. K. Biswas, P. S. Devi, P. K. Chakraborty et al., "Porous antireflective silica coatings with a high spectral coverage by sol-gel spin coating technique," Journal of Materials Science Letters, vol. 22, no. 3, pp. 181-183, 2003.

[10] Q. Zhang, J. Wang, G. Wu, J. Shen, and S. Buddhudu, "Interference coating by hydrophobic aerogel-like $\mathrm{SiO}_{2}$ thin films," Materials Chemistry and Physics, vol. 72, no. 1, pp. 56-59, 2001.

[11] P. Nostell, A. Roos, and B. Karlsson, "Optical and mechanical properties of sol-gel antireflective films for solar energy applications," Thin Solid Films, vol. 351, no. 1-2, pp. 170-175, 1999.

[12] A. Gombert, W. Glaubitt, K. Rose et al., "Glazing with very high solar transmittance," Solar Energy, vol. 62, no. 3, pp. 177-188, 1998.

[13] D. R. Uhlmann, T. Suratwala, K. Davidson, J. M. Boulton, and G. Teowee, "Sol-gel derived coatings on glass," Journal of NonCrystalline Solids, vol. 218, pp. 113-122, 1997.

[14] C. Zha, X. Luo, R. Wang, and B. L. Davies, "Effects of $\mathrm{TiO}_{2}$ and $\mathrm{ZrO}_{2}$ on optical properties of organic-inorganic hybrid polymers and thin films," Journal of Materials Science: Materials in Electronics, vol. 18, p. 331, 2007.

[15] H. H. Nwe, Y. M. Maung, T. T. Win, and K. K. K. Soe, "Photovoltaic properties of mesoporous $\mathrm{TiO}_{2}-\mathrm{ZrO}_{2}$ binary oxide electrode with sawdust organic dye for dye-sensitized solar cell application," Journal of Science, vol. 3, no. 1, p. 197, 2012.

[16] J. Li, Y. Lu, P. Lan et al., "Design, preparation, and durability of $\mathrm{TiO}_{2} / \mathrm{SiO}_{2}$ and $\mathrm{ZrO}_{2} / \mathrm{SiO}_{2}$ double-layer antireflective coatings in crystalline silicon solar modules," Solar Energy, vol. 89, pp. 134-142, 2013.

[17] A. N. Buzynin, Y. N. Buzynin, V. V. Osiko et al., "Antireflection fianite and $\mathrm{ZrO}_{2}$ coatings for solar cells," Bulletin of the Russian Academy of Sciences: Physics, vol. 75, no. 9, pp. 1213-1216, 2011.

[18] M.-T. Wang, T.-H. Wang, and J. Y.-M. Lee, "Electrical conduction mechanism in high-dielectric-constant $\mathrm{ZrO}_{2}$ thin films," Microelectronics Reliability, vol. 45, no. 5-6, pp. 969-972, 2005.

[19] A. Uzum, M. Kuriyama, H. Kanda, Y. Kimura, K. Tanimoto, and S. Ito, "Non-vacuum processed polymer composite antireflection coating films for silicon solar cells," Energies, vol. 9, no. 8, article 633, 2016.

[20] W. Kern and D. A. Puotinen, "Cleaning solutions based on hydrogen peroxide for use in silicon semiconductor technology," RCA Review, vol. 31, pp. 187-206, 1970.

[21] K. Reinhardt and W. Kern, Eds., Handbook of Silicon Wafer Cleaning Technology, William Andrew, 2nd edition, 2008. 

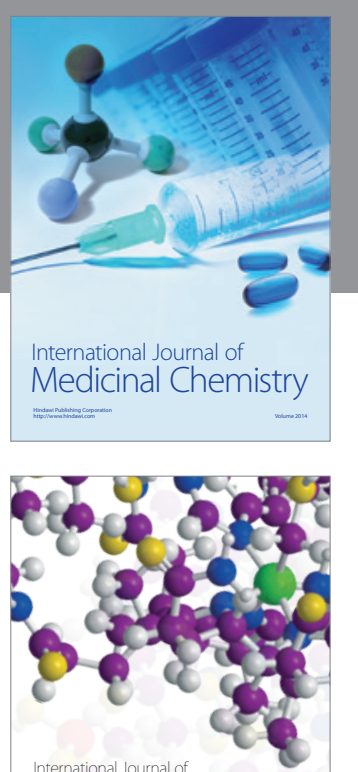

Carbohydrate Chemistry

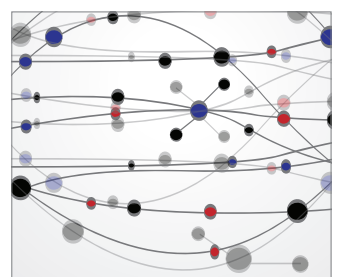

The Scientific World Journal
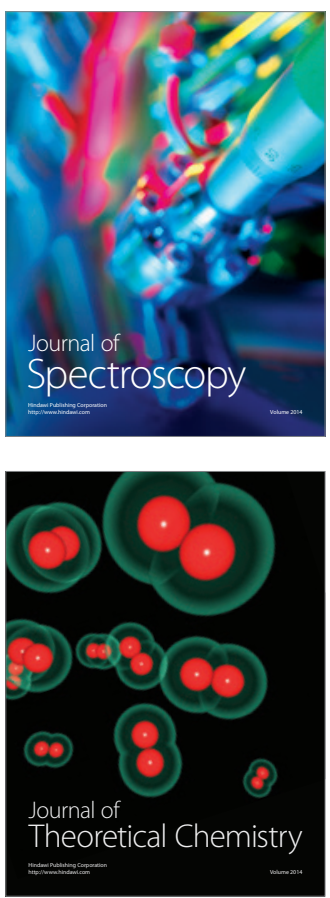
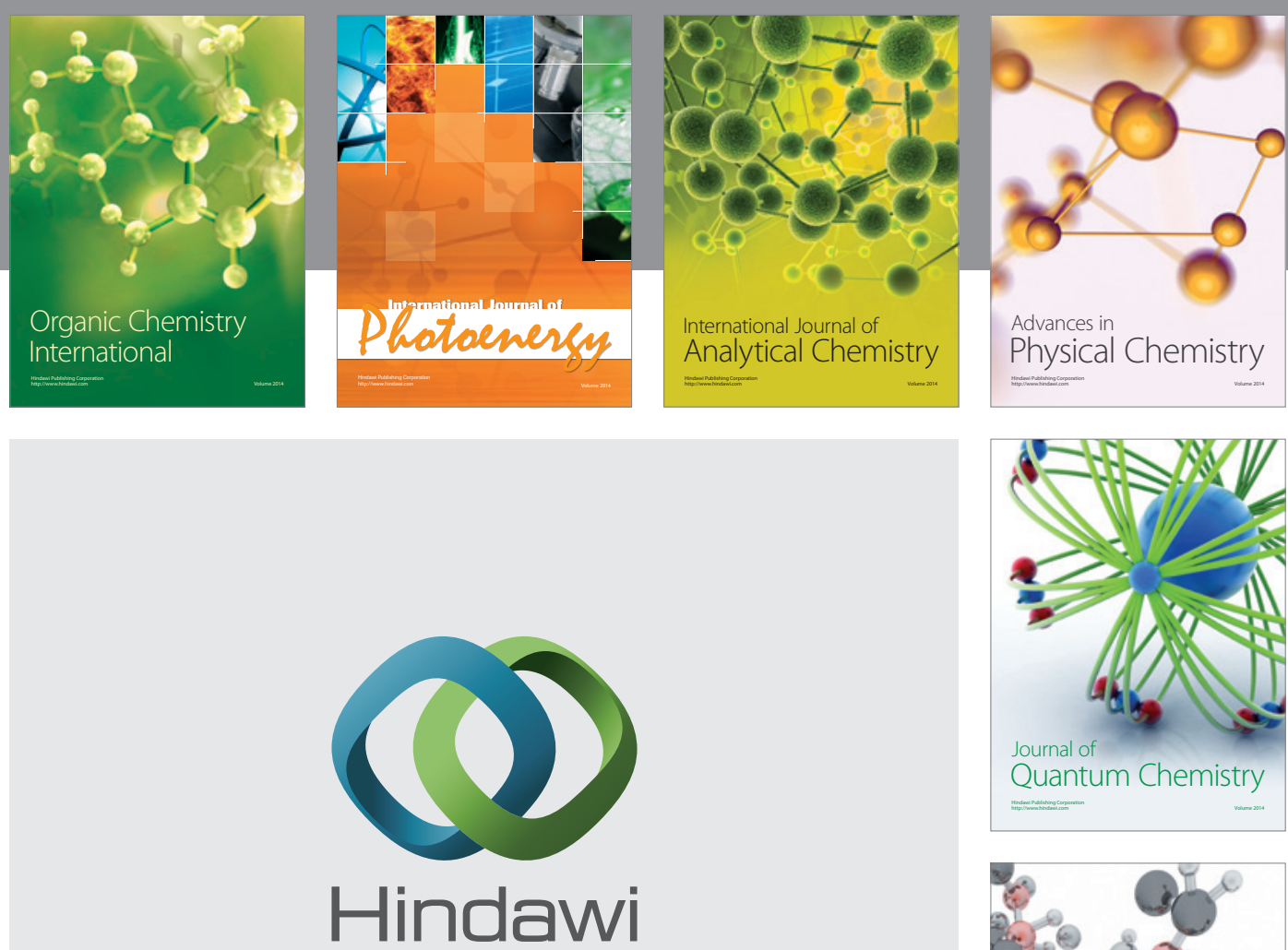

Submit your manuscripts at

https://www.hindawi.com

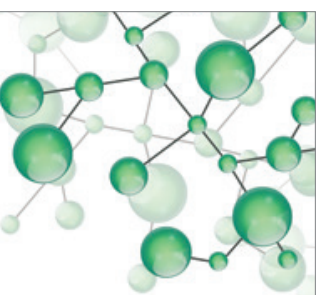

International Journal of

Inorganic Chemistry
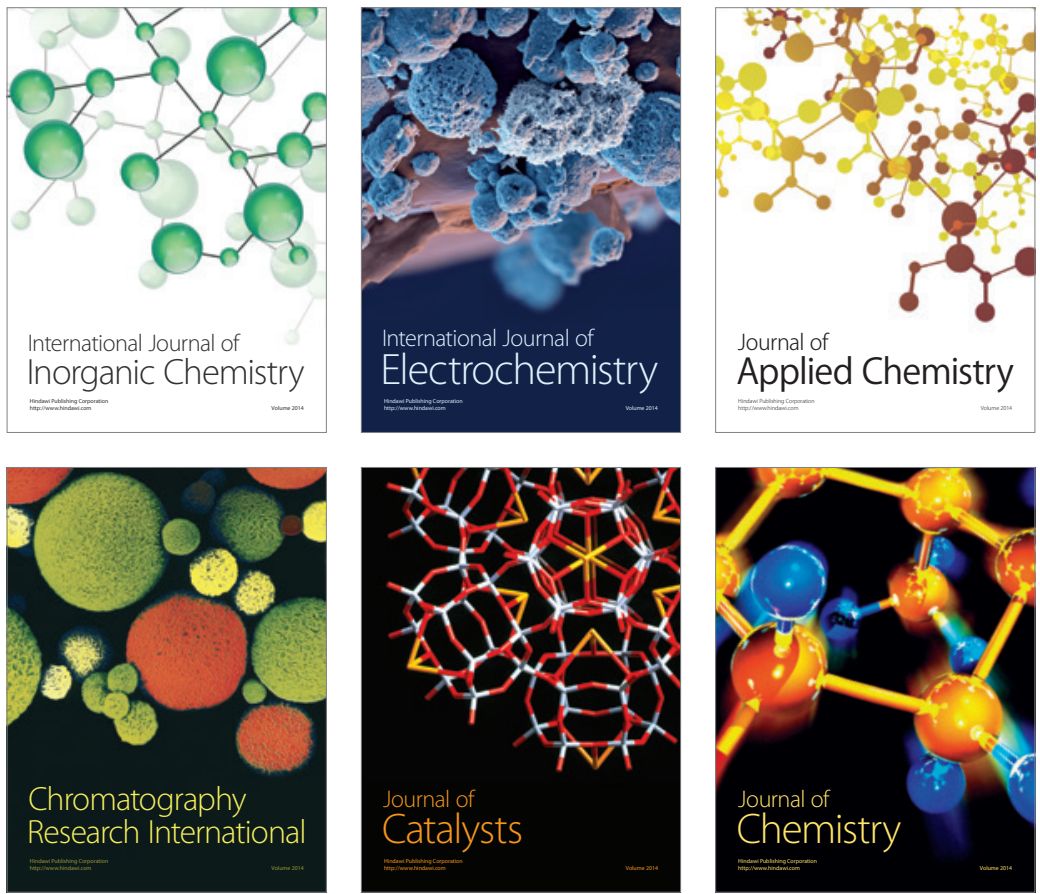

Journal of

Applied Chemistry
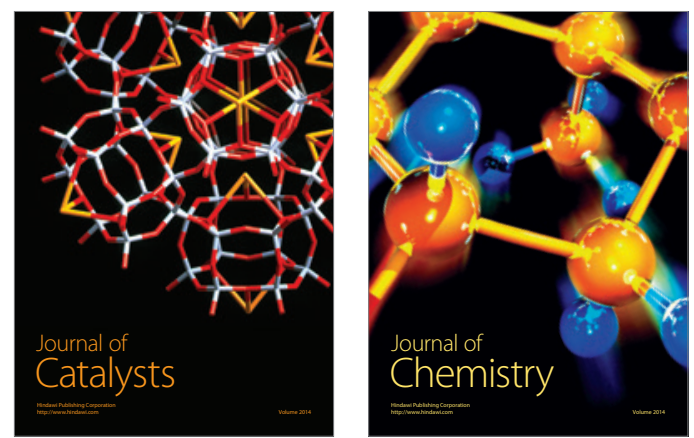
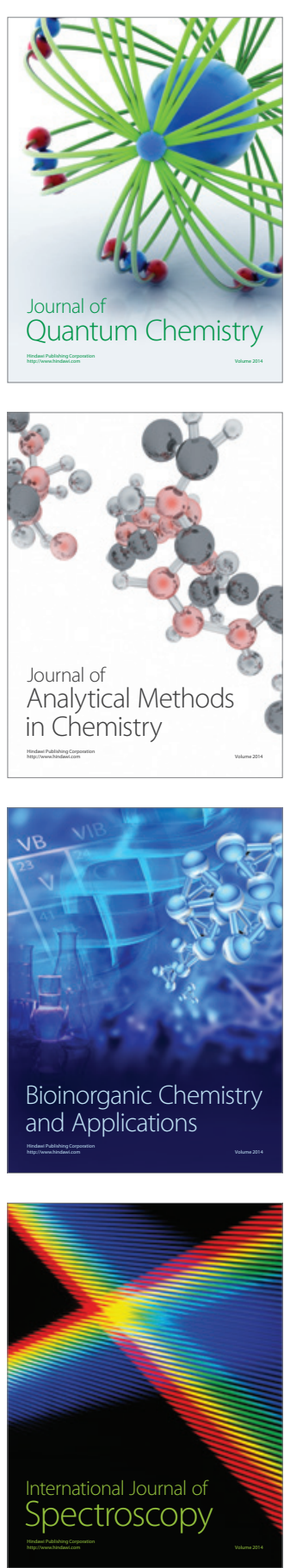